\title{
Nutritional and phytochemical profiles of common pepper (Capsicum spp.) foliage consumed as leafy vegetables in Southeast Nigeria
}

\author{
*Amaechi, N.C., Udeogu, E., Okoronkwo, C.U. and Irondi, C.P. \\ Department of Food Science and Technology, Abia State University, Uturu-Abia State, Nigeria
}

Article history:

Received: 31 December 2020

Received in revised form: 11

February 2021

Accepted: 16 May 2021

Available Online: 26

September 2021

\section{Keywords:}

Pepper foliage,

Vitamins,

Phytochemicals,

Energy density,

Proximate composition,

Minerals

DOI:

https://doi.org/10.26656/fr.2017.5(5).675

\begin{abstract}
Pepper foliage is consumed as a secondary plant part and as a traditional leafy vegetable in some climes. The six commonly consumed pepper species namely Cayenne, Anaheim, Bell, Bird's eye, Scotch Bonnet and Habanero were analysed for their nutrient and phytochemical contents on a fresh weight basis. Proximate composition, vitamins were evaluated while minerals were analysed by the dry ash extraction method. Phytochemicals namely alkaloids, saponins and flavonoids were analysed by gravimetry; tannin and phenols by spectrometry; oxalate by titrimetry and hydrogen cyanide were analysed by alkaline picrate assay. Results indicated a significant difference $(p<0.05)$ in the nutrient and phytochemical contents of the pepper foliage. Moisture ranged between 86.90 to $88.6 \%$ while their energy densities ranged between 34.33 to $45.66 \mathrm{kcal} / 100 \mathrm{~g}$. Anahiem had the highest crude protein while Scotch Bonnet had the highest carbohydrate contents of $3.50 \%$ and $2.70 \%$ respectively. Bird's eye, Bell and Scotch Bonnet had the highest ash, fat and crude fibre contents respectively. The order of concentration of vitamins in the pepper foliage was in this order: Vitamin $\mathrm{C}>$ Vitamin $\mathrm{A}>$ Vitamin $\mathrm{E}>$ Vitamin $\mathrm{B}_{2}>$ Vitamin $\mathrm{B}_{1}>$ Vitamin $\mathrm{B}_{3}$. Scotch Bonnet had the highest calcium and magnesium contents, Cayenne had the highest phosphorus, potassium and iron contents while Anahiem and Bell had the highest zinc and sodium contents respectively. The phytochemical profile indicated that oxalate content of the foliage ranged between 0.14 to $0.28 \mathrm{mg} / 100 \mathrm{~g}$ and this classifies them as low oxalate vegetables. Bird's eye had the highest hydrogen cyanide content $(9.45 \mathrm{mg} / 100 \mathrm{~g})$ while Cayenne had the highest phytate content $(12.72 \%)$. Results indicated the presence of tannins, alkaloids, phytosterols, phenols, flavonoids and saponins. These phytochemicals in the pepper foliage can be beneficial for human wellbeing based on their health-promoting effects.
\end{abstract}

\section{Introduction}

Vegetables perform a crucial role in food and nutrition security (Natesh et al., 2017). They are important for human health due to their vitamins, minerals, phytochemical compounds and dietary fibre content (Ulgeret et al., 2018). Vegetable consumption is influenced by gender, age, income, education, ancestry and health status of an individual (Giskes et al., 2002). Eating leafy vegetables is a component of Africa's culinary tradition and they perform crucial functions in the tradition and food culture of an African family (Otitogu et al., 2014). The culinary knowledge of most vegetables depends primarily on the edible properties of one or more primary parts of the plant (Stephens, 2002). Many plants foliage is not commonly consumed as conventional or exotic vegetables by most human populations due to the lack of knowledge of their edibility. Some secondary plant parts of edible crops are consumed as traditional leafy vegetables in localities of various human populations. One of such plant parts consumed as a vegetable for food by some human populations is the foliage of Capsicum species.

Capsicum species is primarily consumed for its fruits while the leaves are consumed secondarily as another edible plant part after cooking (Stephens, 2002). Capsicum spp. is a genus of flowering plants in the nightshade family Solanacea (Rhodes, 2009). Several Capsicum species abound with some being dominant in certain localities. Generally, pepper leaves are dark green in colour. In China, pepper leaves are used in certain applications such as mouthwashes, topical relief to reduce symptoms of muscle soreness and in Javanese traditional medicine, the leaf juice is used as an antiinflammatory to reduce irritation after childbirth 
(Specialty Produce, 2020). Pepper leaves are sold in fresh markets in some places such as Asia, Southeast Asia, South and Central America and Africa (Specialty Produce, 2020). They are cooked as greens and are reported to be mildly bitter compared to moringa leaves (Abilgos-Ramos et al., 2012). In Southeast Nigeria, it is consumed in some localities such as Izzi clan in Ebonyi State Nigeria as a traditional leafy vegetable. Nutritionally, pepper leaves are reported to be a good source of vitamins A, B and antioxidants (Specialty Produce, 2020). The nutritional benefits such as its antioxidant properties is in part due to the presence of certain phytochemicals secreted as the plant's secondary metabolites.

The quantity and quality of nutrients and phytochemicals in pepper foliage (leaves) may influence the usefulness of varieties/species for culinary and medicinal purposes. It is in view of this that six varieties that are commonly consumed in the southeast of Nigeria were evaluated for their nutrient and phytochemical contents. These include Cayenne, Anahiem, Bell and Bird's eye pepper and they are varieties of Capsicum annum as well as Scotch Bonnet and Habanero pepper which are varieties of Capsicum chinense (Bosland, 1996; Brown et al., 2013). The knowledge of the nutritional value of these varieties will provide information about the species with the best macronutrient composition but with low antinutritional phytochemicals. This will enhance cultivation not only for the fruits but also for the foliage, hence, enhance food and nutrition security as well as reduce over-dependence on exotic vegetables.

\section{Materials and methods}

\subsection{Collection and preparation of samples}

Pepper leaves used for the study was got after planting seeds of the different varieties. Fresh pepper fruits were purchased from a supermarket (Shoprite) while some were from a local market and were identified by a botanist. Seeds were extracted from the respective fruits and planted in a farmyard in Ahiaeke-Ndume situated N5 ${ }^{\circ} 30^{\prime} 37^{\prime \prime}$ and E7 $7^{\circ} 31^{\prime} 44^{\prime \prime}$ in Umuahia North Local Government Area of Abia State Nigeria. Planting was done in March 2018. The seedlings were planted $12 \times 15$ inches spacing on ridges and allowed to grow for a period between 65 and 70 days to produce enough foliage for analysis. Leaves (the foliage) were used for proximate composition, vitamins, minerals and phytochemical analysis. Harvest was done and analysis was done on a fresh weight basis. Prior to each analysis, each plant foliage was picked, washed and drained of water. The pepper species used in this work is shown in Figure 1 .

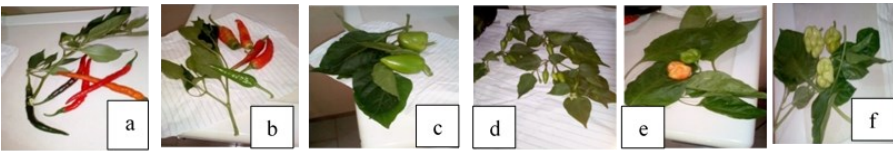

Figure 1. Pepper species used in the work: (a) Cayenne (b) Anaheim (c) Bell pepper (d) Bird's eye (e) Scotch Bonnet (f) Habanero.

\subsection{Proximate analysis and energy value calculation}

Proximate composition (protein, lipid, fibre, ash, moisture and carbohydrate) of the respective pepper foliage were determined by the method described by James (1995). In brief, moisture was determined by the gravimetric method by heating in an oven at $105^{\circ} \mathrm{C}$ for 3 hrs to constant weight; total nitrogen was determined by the Kjeldahl method and converted to protein using the factor 6.25. Total fat was extracted by the Soxhlet technique using hexane and subsequently evaluated by gravimetry. Ash was determined by gravimetry of incinerated sample in a muffle furnace at $550^{\circ} \mathrm{C}$ for 3 hrs. Fibre was analysed after hydrolysis of the defatted sample using $1.25 \% \mathrm{H}_{2} \mathrm{SO}_{4}$ boiled under reflux for 30 mins followed by hydrolysis using $1.25 \% \mathrm{NaOH}$ and boiled under reflux for another 30 mins. Fibre was determined by gravimetry after drying the recovered residue in an oven at $105^{\circ} \mathrm{C}$ for $3 \mathrm{hrs}$ to a constant weight. Calorific values of the leaves were estimated by multiplying the percentages of carbohydrate, fat and protein by the factors $3.57,8.37$ and 2.44 respectively (FAO, 2003).

\subsection{Determination of minerals}

The mineral content of each pepper foliage was determined by the dry ash extraction method described by AOAC (2005). Five $g$ of each pepper foliage was incinerated in a muffle furnace at $550^{\circ} \mathrm{C}$ for $3 \mathrm{hrs}$. Three $\mathrm{mL}$ concentrated $\mathrm{HCl}$ was added to each ashed sample and transferred into a $250 \mathrm{~mL}$ volumetric flask. Deionised water was used to rinse the crucible used for ashing three times and all the solutions were pooled into respective ashed foliage samples before making up to $100 \mathrm{~mL}$ mark using deionised water. The diluted digest was used to analyse the different mineral elements. Sodium and potassium were analysed using an FP640 Flame photometer (Wincom, Hunan China). Phosphorus and zinc were analysed by determining the absorbance of the colour complex formed for molybdovanadate and zinc, respectively. The absorbance was read at $400 \mathrm{~nm}$ for phosphorus and $615 \mathrm{~nm}$ for zinc (Säbel, 2010) using a $\mathrm{UV} / \mathrm{V}$ is $\quad 721 \mathrm{~N}$ spectrophotometer (Measuretech Instrument, Shanghai China). EDTA titration was used for the determination of calcium and magnesium (AOAC, 2005). Iron was analysed by orthophenanthrolinered ferrous complex method (Jackson, 1969). 


\subsection{Determination of vitamins}

The B vitamins, vitamin A and Vitamin E contents of the pepper foliage samples were estimated spectrophotometrically (UV/Vis 721N spectrophotometer, Measuretech Instrument, Shanghai China) using $1 \mathrm{~cm}$ pathlength cuvette, according to the methods described by Okwu and Emenike (2006) with some modifications. Briefly, $5 \mathrm{~g}$ of each sample was homogenized and extracted using a mixture of absolute ethanol and 5\% potassium hydroxide (10:1) and boiled for $30 \mathrm{mins}$ under reflux before adding petroleum ether. The extract mix was evaporated to dryness on a rotary evaporator. Small amounts of the residue were redissolved in appropriate carrier solvents for each vitamin. Vitamin standards were prepared in the carrier solvents at different concentrations. Their absorbance was read and used to create the calibration curves used to calculate the concentration of the vitamin on a dry weight basis. The absorbance of the vitamins was monitored as followed: thiamine (vitamin B1) at $360 \mathrm{~nm}$, riboflavin (Vitamin B2) at $510 \mathrm{~nm}$, niacin (vitamin B3) at $470 \mathrm{~nm}$, vitamin $A$ at $450 \mathrm{~nm}$ and vitamin $E$ at 295 nm.

Vitamin $\mathrm{C}$ was determined titrimetrically after homogenizing each sample in $50 \mathrm{~mL} 5.6 \mathrm{mM}$ EDTA solution. The homogenized samples were filtered using Whatman No.1 filter paper. Approximately $10 \mathrm{~mL}$ of $30 \%$ potassium iodide was added to $20 \mathrm{~mL}$ of filtrate and mixed thoroughly. The mixture was titrated against $0.1 \mathrm{M}$ $\mathrm{CuSO}_{4}$ to a dark endpoint using $1 \%$ starch solution as the indicator (Okwu and Emenike, 2006).

\subsection{Phytochemical determination}

The Phytochemicals in each pepper foliage samples were investigated. Total polyphenols were determined by the Folin-Ciocalteu assay (AOAC, 2005), while oxalate was determined by titrimetry as described by (Gupta et al., 2005). Total tannins, cyanides and phytic acid contents were determined by Folin-Dennis assay, alkaline picrate assay, and 2,2-bipyrimidine solution assay, respectively, as described by (Yasmin et al.,
2008). Gravimetric estimations of total alkaloids, total saponins and total flavonoids were carried out following the protocols described by Harborne (1998). Phytosterol was determined spectrophotometrically after precipitation (Kasal et al., 2010).

\subsection{Statistical analysis}

One way analysis of variance (ANOVA) was used to analyse the data (two replicates) using SPSS (IBM, Version 21, USA). Multiple comparisons were made for all experiments using Duncan's Multiple Range Test at a probability of $\mathrm{p}=0.05$ and the results were expressed as mean \pm standard deviation.

\section{Results and discussion}

\subsection{Proximate composition}

The proximate composition results of the pepper foliage are shown in Table 1. Moisture content ranged between 86 to $88 \%$ with foliage from Habanero pepper and Anahiem pepper having the highest and least value respectively. There was a significant difference $(p<0.05)$ in moisture content of the pepper foliage except those of Cayenne, Bird's eye and Bell. The moisture content of the pepper foliages was comparable to the moisture content of Rumex vesicarius (89.75\%) (Alfawaz, 2006), some indigenous vegetables grown in Sri Lanka (Nadeeshani et al., 2018), Cnidoscolus acontifolius (82.16\%), Telferia occidentalis (86.28\%) (Otitoju et al., 2014). Moisture in vegetables affects the succulent nature amongst other compounds such as cellulose network and lignin content. Water is an important constituent in food composition databases as it is one of the most diverse components in plant foods that affect the composition of food generally (Greenfield and Southgate, 2003). The high moisture content of the pepper foliage indicates freshness and perishability due to high water activity.

The crude protein content of the foliage showed a range of 1.20 to $3.50 \%$. Anahiem and Scotch Bonnet pepper foliage had the maximum and minimum crude

Table 1. Proximate composition and energy values of pepper foliage

\begin{tabular}{cccccccc}
\hline Sample & Moisture (\%) & $\begin{array}{c}\text { Crude protein } \\
(\%)\end{array}$ & Fat (\%) & $\begin{array}{c}\text { Crude Fibre } \\
(\%)\end{array}$ & Ash (\%) & $\begin{array}{c}\text { Carbohydrate } \\
(\%)\end{array}$ & $\begin{array}{c}\text { Energy Value } \\
(\mathrm{kcal} / 100 \mathrm{~g})\end{array}$ \\
\hline Anahiem & $86.00 \pm 0.00^{\mathrm{d}}$ & $3.50 \pm 0.00^{\mathrm{a}}$ & $2.60 \pm 0.00^{\mathrm{c}}$ & $2.50 \pm 0.00^{\mathrm{b}}$ & $2.75 \pm 0.00^{\mathrm{b}}$ & $2.65 \pm 0.00^{\mathrm{a}}$ & $39.76 \pm 0.00^{\mathrm{b}}$ \\
Cayenne & $86.90 \pm 0.14^{\mathrm{c}}$ & $3.28 \pm 0.11^{\mathrm{b}}$ & $2.75 \pm 0.07^{\mathrm{bc}}$ & $2.00 \pm 0.00^{\mathrm{c}}$ & $2.50 \pm 0.00^{\mathrm{c}}$ & $2.58 \pm 0.32^{\mathrm{a}}$ & $40.20 \pm 0.29^{\mathrm{b}}$ \\
Bird's eye & $87.10 \pm 0.14^{\mathrm{c}}$ & $3.15 \pm 0.00^{\mathrm{c}}$ & $2.80 \pm 0.00^{\mathrm{b}}$ & $2.40 \pm 0.14^{\mathrm{b}}$ & $3.20 \pm 0.07^{\mathrm{a}}$ & $1.35 \pm 0.55^{\mathrm{b}}$ & $35.94 \pm 1.26^{\mathrm{c}}$ \\
Scotch Bonnet & $88.60 \pm 0.14^{\mathrm{a}}$ & $1.20 \pm 0.00^{\mathrm{e}}$ & $2.60 \pm 0.00^{\mathrm{c}}$ & $2.90 \pm 0.14^{\mathrm{a}}$ & $2.00 \pm 0.00^{\mathrm{d}}$ & $2.70 \pm 0.00^{\mathrm{a}}$ & $34.33 \pm 0.00^{\mathrm{d}}$ \\
Bell pepper & $87.00 \pm 0.00^{\mathrm{c}}$ & $2.80 \pm 0.00^{\mathrm{d}}$ & $3.70 \pm 0.14^{\mathrm{a}}$ & $1.80 \pm 0.00^{\mathrm{d}}$ & $2.50 \pm 0.00^{\mathrm{c}}$ & $2.20 \pm 0.14^{\mathrm{a}}$ & $45.66 \pm 0.68^{\mathrm{a}}$ \\
Habanero & $88.00 \pm 0.00^{\mathrm{b}}$ & $3.15 \pm 0.00^{\mathrm{c}}$ & $2.40 \pm 0.00^{\mathrm{d}}$ & $2.80 \pm 0.00^{\mathrm{a}}$ & $1.30 \pm 0.14^{\mathrm{e}}$ & $2.35 \pm 0.14^{\mathrm{a}}$ & $36.16 \pm 0.51^{\mathrm{c}}$ \\
\hline
\end{tabular}

Values are presented as means \pm standard deviation. Values with different superscripts in the same column are significantly different $(p<0.05)$ 
protein content respectively. There was no significant differences $(p>0.05)$ in crude protein contents of Bird's eye and Habanero pepper foliage. The crude protein content of the pepper foliage is quite low, hence cannot make a significant protein contribution to vegan meals. However, Anahiem pepper foliage crude protein content was comparable to the crude protein of a Amaranthus hybridus (3.58\%) (Medoua and Oldewage-Theron, 2014) but lower than the crude protein content of Amaranthus viridis (4.25\%), Sesbania grandiflora (7.17\%) (Nadeeshani et al., 2018) but lower than crude protein for Psychotria spp (11.75\%), C. acontifolius (4.83\%), T.occidentalis (5.26\%) (Otitoju et al., 2014).

Fat content ranged between 2.40 to $3.70 \%$ with Habanero and Bell pepper foliage having the lowest and highest values respectively. The fat content of all the pepper foliage was fairly higher than the fat content of all the vegetables reported by Nadeeshani et al. (2018) which ranged between 0.29 and $1.81 \mathrm{~g} / 100 \mathrm{~g}, C$. acontifolius (1.61\%), T. occidentalis (1.25\%) (Otitoju et al., 2014); $R$. vesicarius (0.66\%) (Alfawaz, 2006). The low-fat content of the pepper foliage agrees with the findings of Ejoh et al. (1996) who reported vegetables as a poor source of fat.

The crude fibre content of the pepper foliage ranged between 1.80 to $2.90 \%$. There were no significant differences $(p>0.05)$ in crude fibre content in some of the pepper foliage (Table 1). Fibre is indigestible in the upper gastrointestinal tract of humans but nutritionally important. Fibre helps to maintain good digestive health, lower the risk of certain disease conditions such as diabetes mellitus (Type 2), cancer of the digestive system, improve skin health by flushing toxins of the body as well as reduce the risk of metabolic syndromes linked to coronary heart disease and stroke (Nutrition Source, 2020).

Ash is a measure of the mineral content of foods. Ash content of the pepper foliage ranged between 1.30 and $3.20 \%$. Bird's eye pepper foliage had the highest ash content, and this indicates that it will provide more minerals than the other pepper foliage studied. Carbohydrate contents of all the pepper foliage were generally low. Energy values ranged between 34.33 and $45.66 \mathrm{Kcal} / 100 \mathrm{~g}$. Bell pepper foliage had the highest energy value while Scotch Bonnet pepper foliage had the least value. Energy values of the pepper foliage were higher than the energy values of A. hybridus (23.70 $\mathrm{kcal} / 100 \mathrm{~g}$ ) (Medoua and Oldewage-Theron, 2014), Amaranthus incurvatus (13.7 kcal/100 g) (Asibey-Berko and Tayie, 1999) but lower than energy values of Corchorus tridens $(48.7 \mathrm{kcal} / 100 \mathrm{~g})$, Solanum nigrum $(47.5 \mathrm{Kcal} / 100 \mathrm{~g})$ and Ipomea batatas leaves (48.70 $\mathrm{kcal} / 100 \mathrm{~g}$ ) all on a fresh weight basis (Asibey-Berko and Tayie, 1999). The low energy of foods on fresh weight basis can be attributed to low total solids hence low nutrient densities due to high moisture content.

\subsection{Vitamins}

The results indicated the presence of water-soluble vitamins $B_{1}, B_{2}$, niacin $\left(B_{3}\right)$ and $C$ as well as fat-soluble vitamins $\mathrm{A}$ and $\mathrm{E}$. As shown in Table 2, these vitamins varied significantly $(p<0.05)$ in the various pepper foliage. The order of concentration of these vitamins in the pepper foliage was: Vit. $\mathrm{C}>$ Vit. $\mathrm{A}>$ Vit. $\mathrm{E}>$ Vit. $\mathrm{B}_{2}$ $>$ Vit. $\mathrm{B}_{1}>$ Vit. $\mathrm{B}_{3}$. The range of concentration of the vitamins in the pepper foliage were as follows: Vitamin A: $4.89-7.83 \mathrm{mg} / 100 \mathrm{~g}$; Vitamin $\mathrm{B}_{1}: 1.06-1.40 \mathrm{mg} / 100 \mathrm{~g}$; Vitamin $\mathrm{B}_{2}: 2.57-3.22 \mathrm{mg} / 100 \mathrm{~g}$; Vitamin $\mathrm{B}_{3}: 0.12-0.32$ $\mathrm{mg} / 100 \mathrm{~g}$; Vitamins C: $59.45-87 \mathrm{mg} / 100 \mathrm{~g}$ and Vitamin E: $4.53-5.81 \mathrm{mg} / 100 \mathrm{~g}$. Cayenne pepper foliage had the highest vitamins $A, B_{1}, B_{3}$ and $E$ contents while Anahiem pepper foliage had the highest Vitamins $B_{2}$ and $\mathrm{C}$ contents. Vitamin A content of the foliage have the potential to meet the recommended dietary allowance (RDA) of 400 to $1300 \mu \mathrm{g}$ /day for different life stages and gender groups of healthy individuals (FNB/IM/NA, 2001). Vitamin A content of Anahiem, Cayenne, Bird's eye and Scotch Bonnet were higher than Vitamin A contents of Psychotriaspp $(5.31 \mathrm{mg} / 100 \mathrm{~g}), \quad C$. acontifolius $(0.66 \mathrm{mg} / 100 \mathrm{~g})$ and $T$. occidentalis $(1.23$ $\mathrm{mg} / 100 \mathrm{~g}$ ) (Otitoju et al., 2014). Vitamin A is needed for normal vision, gene expression, reproduction, embryonic development and immune function (FNB/IM/NA, 2001). Vitamin $\mathrm{E}$ content of the pepper foliage is enough to meet with the adequate intake of 4-5 $\mathrm{mg}$ /day for infants and partly for intake of 6-7 $\mathrm{mh} /$ day for children of healthy individuals (FNB/IM/NA, 2000). Older children, males and females of healthy individuals will have to supplement from other food sources. Vitamin E is a nonspecific chain breaking antioxidant (FNB/IM/NA, 2000). Its antioxidative activity is mainly in lipid bilayer of cells.

Vitamin $\mathrm{B}_{1}$ content of the pepper foliage were higher than vitamin $\mathrm{B}_{1}$ content of fresh T.occidentalis $(0.08 \mathrm{mg} /$ g)(Okpalamma et al., 2013) and Pterocarpus mildbraedii $(0.25 \mathrm{mg} / \mathrm{g})\left(\right.$ Okpalamma et al., 2016). Vitamin $\mathrm{B}_{1}$ of the pepper foliage can meet $0.2-1.2 \mathrm{mg} /$ day RDA for infants, children, males and females of healthy individuals relatively; but pregnant and lactating females require 1.4 $\mathrm{mg} /$ day (FMN/IM/NA, 1998) and so will need supplementation from other food sources. Vitamin $\mathrm{B}_{2}$ of the pepper foliages will be sufficient to meet with RDA of 0.3-1.6 mg/day (FNB/IM/NA, 1998) for different life stages and gender groups of healthy individuals. Vitamin $\mathrm{C}$ content of the all the pepper foliage were higher than $36.6 \mathrm{mg} / 100 \mathrm{~g}$ reported as Vitamin C content of Amaranthus hybridus (Medoua and Oldewage-Theron, 
Table 2. Vitamin content of pepper foliage

\begin{tabular}{ccccccc}
\hline Sample & $\begin{array}{c}\text { Vitamin A } \\
(\mathrm{mg} / 100 \mathrm{~g})\end{array}$ & $\begin{array}{c}\text { Vitamin } \mathrm{B}_{1} \\
(\mathrm{mg} / 100 \mathrm{~g})\end{array}$ & $\begin{array}{c}\text { Vitamin } \mathrm{B}_{2} \\
(\mathrm{mg} / 100 \mathrm{~g})\end{array}$ & $\begin{array}{c}\text { Vitamin } \mathrm{B}_{3} \\
(\mathrm{mg} / 100 \mathrm{~g})\end{array}$ & $\begin{array}{c}\text { Vitamin C } \\
(\mathrm{mg} / 100 \mathrm{~g})\end{array}$ & $\begin{array}{c}\text { Vitamin E } \\
(\mathrm{mg} / 100 \mathrm{~g})\end{array}$ \\
\hline Anahiem & $6.59 \pm 0.09^{\mathrm{b}}$ & $1.26 \pm 0.0^{\mathrm{b}}$ & $3.22 \pm 0.0^{\mathrm{a}}$ & $0.18 \pm 0.0^{\mathrm{b}}$ & $87.00 \pm 0.2^{\mathrm{a}}$ & $4.72 \pm 0.00^{\mathrm{e}}$ \\
Cayenne & $7.38 \pm 0.00^{\mathrm{a}}$ & $1.40 \pm 0.0^{\mathrm{a}}$ & $3.09 \pm 0.0^{\mathrm{b}}$ & $0.32 \pm 0.0^{\mathrm{a}}$ & $59.45 \pm 0.0^{\mathrm{c}}$ & $5.81 \pm 0.03^{\mathrm{a}}$ \\
Bird's eye & $6.22 \pm 0.00^{\mathrm{c}}$ & $1.06 \pm 0.0^{\mathrm{e}}$ & $2.84 \pm 0.0^{\mathrm{c}}$ & $0.29 \pm 0.2^{\mathrm{a}}$ & $66.39 \pm 0.1^{\mathrm{b}}$ & $5.06 \pm 0.00^{\mathrm{c}}$ \\
Scotch Bonnet & $6.42 \pm 0.04^{\mathrm{b}}$ & $1.12 \pm 0.0^{\mathrm{d}}$ & $2.57 \pm 0.0^{\mathrm{e}}$ & $0.17 \pm 0.3^{\mathrm{b}}$ & $59.59 \pm 0.1^{\mathrm{c}}$ & $5.72 \pm 0.00^{\mathrm{b}}$ \\
Bell pepper & $5.65 \pm 0.00^{\mathrm{d}}$ & $1.21 \pm 0.0^{\mathrm{c}}$ & $2.61 \pm 0.0^{\mathrm{e}}$ & $0.28 \pm 0.0^{\mathrm{a}}$ & $54.97 \pm 0.3^{\mathrm{d}}$ & $4.53 \pm 0.00^{\mathrm{f}}$ \\
Habanero & $4.89 \pm 0.13^{\mathrm{e}}$ & $1.17 \pm 0.0^{\mathrm{c}}$ & $2.74 \pm 0.0^{\mathrm{d}}$ & $0.12 \pm 0.0^{\mathrm{c}}$ & $59.34 \pm 0.16^{\mathrm{c}}$ & $4.90 \pm 0.00^{\mathrm{d}}$ \\
\hline
\end{tabular}

Values are presented as means \pm standard deviation. Values with different superscripts in the same column are significantly different $(\mathrm{p}<0.05)$

2014).Vitamin C content of the pepper foliage will be sufficient to meet with RDA for infants (40-50 mg/day), children 1-8 years (15-25 mg/day) but not sufficient to meet with RDA of $>75 \mathrm{mg} /$ day (FNB/IM/NA, 2000) for adult males and females of different life stages of healthy individuals. Therefore, adults have to supplement for Vitamin C from other food sources.

\subsection{Minerals}

The mineral content of the various pepper foliage is shown in Table 3. Results indicated a significant difference $(p<0.05)$ in mineral content of the pepper foliage. The order of concentration of minerals was potassium $>$ sodium $>$ magnesium $>$ calcium $>$ phosphorus $>$ iron $>$ zinc. The concentration of the minerals was as follows: Calcium: $31.32-43.33 \mathrm{mg} / 100$ g; Magnesium: 34.50-74.51 mg/100 g; Phosphorus: 23.89-45.02 mg/100 g; Sodium: 75.49-87.43 mg/100 g; Potassium: $73.45-95.17 \mathrm{mg} / 100 \mathrm{~g}$; Iron: 2.72-5.77 $\mathrm{mg} / 100 \mathrm{~g}$ and Zinc: $1.37-2.47 \mathrm{mg} / 100 \mathrm{~g}$. Scotch Bonnet pepper foliage had the highest calcium and magnesium contents; Cayenne pepper foliage had the highest phosphorus, potassium and iron contents; Anahiem pepper foliage had the highest zinc content while Bell pepper foliage had the highest sodium content.

Calcium and magnesium contents of the pepper foliage were higher than calcium and magnesium content of vegetables reported by Otitoju et al. (2014) which ranged between $0.96-3.09 \mathrm{mg} / 100 \mathrm{~g}$ and magnesium

Table 3. Mineral content of pepper foliage

\begin{tabular}{cccccccc}
\hline Sample & $\begin{array}{c}\text { Calcium } \\
(\mathrm{mg} / 100 \mathrm{~g})\end{array}$ & $\begin{array}{c}\text { Magnesium } \\
(\mathrm{mg} / 100 \mathrm{~g})\end{array}$ & $\begin{array}{c}\text { Phosphorus } \\
(\mathrm{mg} / 100 \mathrm{~g})\end{array}$ & $\begin{array}{c}\text { Sodium } \\
(\mathrm{mg} / 100 \mathrm{~g})\end{array}$ & $\begin{array}{c}\text { Potassium } \\
(\mathrm{mg} / 100 \mathrm{~g})\end{array}$ & $\begin{array}{c}\text { Iron } \\
(\mathrm{mg} / 100 \mathrm{~g})\end{array}$ & $\begin{array}{c}\text { Zinc } \\
(\mathrm{mg} / 100 \mathrm{~g})\end{array}$ \\
\hline Anahiem & $32.71 \pm 0.34^{\mathrm{d}}$ & $68.02 \pm 0.25^{\mathrm{b}}$ & $30.54 \pm 0.24^{\mathrm{d}}$ & $78.59 \pm 0.00^{\mathrm{e}}$ & $92.10 \pm 0.00^{\mathrm{b}}$ & $4.24 \pm 0.08^{\mathrm{b}}$ & $2.47 \pm 0.00^{\mathrm{a}}$ \\
Cayenne & $31.32 \pm 0.36^{\mathrm{e}}$ & $46.39 \pm 0.00^{\mathrm{d}}$ & $45.02 \pm 0.23^{\mathrm{a}}$ & $84.20 \pm 0.23^{\mathrm{b}}$ & $95.17 \pm 0.00^{\mathrm{a}}$ & $5.77 \pm 0.00^{\mathrm{a}}$ & $2.21 \pm 0.04^{\mathrm{b}}$ \\
Bird's eye & $38.05 \pm 0.00^{\mathrm{c}}$ & $41.69 \pm 0.21^{\mathrm{e}}$ & $32.56 \pm 0.27^{\mathrm{b}}$ & $80.17 \pm 0.00^{\mathrm{c}}$ & $81.45 \pm 0.00^{\mathrm{d}}$ & $4.25 \pm 0.18^{\mathrm{b}}$ & $1.76 \pm 0.00^{\mathrm{e}}$ \\
Scotch Bonnet & $43.33 \pm 0.35^{\mathrm{a}}$ & $74.51 \pm 0.41^{\mathrm{a}}$ & $31.09 \pm 0.00^{\mathrm{c}}$ & $79.22 \pm 0.00^{\mathrm{d}}$ & $86.29 \pm 0.00^{\mathrm{c}}$ & $3.43 \pm 0.23^{\mathrm{c}}$ & $2.07 \pm 0.04^{\mathrm{c}}$ \\
Bell pepper & $32.95 \pm 0.00^{\mathrm{d}}$ & $34.50 \pm 0.43^{\mathrm{f}}$ & $26.31 \pm 0.19^{\mathrm{e}}$ & $87.43 \pm 0.36^{\mathrm{a}}$ & $76.03 \pm 0.29^{\mathrm{e}}$ & $2.72 \pm 0.00^{\mathrm{d}}$ & $1.92 \pm 0.06^{\mathrm{d}}$ \\
Habanero & $41.77 \pm 0.17^{\mathrm{b}}$ & $56.19 \pm 0.00^{\mathrm{c}}$ & $23.89 \pm 0.00^{\mathrm{f}}$ & $75.49 \pm 0.14^{\mathrm{f}}$ & $73.45 \pm 0.39^{\mathrm{f}}$ & $2.96 \pm 0.00^{\mathrm{d}}$ & $1.37 \pm 0.00^{\mathrm{f}}$ \\
\hline
\end{tabular}

Values are presented as means \pm standard deviation. Values with different superscripts in the same column are significantly different $(\mathrm{p}<0.05)$ magnesium contents of selected leafy vegetables grown in Sri Lanka which ranged between $1.52-11.17 \mathrm{mg} / 100 \mathrm{~g}$ and $0.51-1.59 \mathrm{mg} / 100 \mathrm{~g}$ respectively (Nadeeshani et al., 2018). Phosphorus content of the pepper foliage were lower than phosphorus content of vegetables reported by Otitoju et al. (2014) which ranged between 58.34 and $243.70 \mathrm{mg} / 100 \mathrm{~g}$ on fresh weight basis. Phosphorus, sodium and potassium content of the pepper foliage will be insufficient to meet with $100-1250 \mathrm{mg} /$ day for phosphorus (FNB/IM/NA, 1997), 0.12-1.5g/day for sodium and 0.4-5.1g/day requirement for potassium (FNB/IM/NA, 2004) needed for different life stages of healthy individuals. Therefore, there is need for supplementation from other food sources. sodium is required to maintain extracellular fluid volume and for normal cell function while potassium is required for the maintenance of both intracellular and extracellular fluid volume required for normal cell function as well as blunting the rise of blood pressure in response to excess sodium intake (FMB/IM/NA, 2004).

Zinc and iron contents of the pepper foliage evaluated were higher than zinc and iron contents of some selected Sri Lanka vegetables which ranged between 4.03 and $34.69 \mu \mathrm{g} / \mathrm{g}$ for zinc and 40.65 and $207.34 \mu \mathrm{g} / \mathrm{g}$ for iron (Nadeeshani et al., 2018). In consuming any of this pepper foliage, there is a need to supplement from other food sources in order to meet with RDA of 2-13 mg/d and 7-27 mg/day for zinc and iron respectively (FNB/IM/NA, 2001). Zinc and iron are 
Table 4. Phytochemical content of pepper foliage

\begin{tabular}{lcccccc}
\hline \multirow{2}{*}{ Phytochemical } & \multicolumn{5}{c}{ Pepper Sample } \\
\cline { 2 - 7 } & Anahiem & Cyanenne & Bird's eye & Scotch Bonnet & Bell Pepper & Habanero \\
\hline HCN (mg/kg) & $8.45 \pm 0.00^{\mathrm{d}}$ & $8.43 \pm 0.04^{\mathrm{d}}$ & $9.45 \pm 0.02^{\mathrm{a}}$ & $6.95 \pm 0.00^{\mathrm{e}}$ & $8.91 \pm 0.04^{\mathrm{c}}$ & $9.41 \pm 0.02^{\mathrm{b}}$ \\
Oxalate (mg/100 g) & $0.28 \pm 0.06^{\mathrm{a}}$ & $0.18 \pm 0.00^{\mathrm{bc}}$ & $0.24 \pm 0.00^{\mathrm{ab}}$ & $0.14 \pm 0.02^{\mathrm{c}}$ & $0.16 \pm 0.01^{\mathrm{c}}$ & $0.18 \pm 0.00^{\mathrm{bc}}$ \\
Alkaloid (\%) & $3.10 \pm 0.14^{\mathrm{c}}$ & $4.85 \pm 0.21^{\mathrm{a}}$ & $4.00 \pm 0.00^{\mathrm{b}}$ & $3.90 \pm 0.14^{\mathrm{b}}$ & $5.10 \pm 0.10^{\mathrm{a}}$ & $3.00 \pm 0.14^{\mathrm{c}}$ \\
Saponin (\%) & $3.00 \pm 0.00^{\mathrm{a}}$ & $2.10 \pm 0.14^{\mathrm{c}}$ & $1.00 \pm 0.00^{\mathrm{d}}$ & $1.90 \pm 0.14^{\mathrm{c}}$ & $2.90 \pm 0.14^{\mathrm{a}}$ & $2.50 \pm 0.00^{\mathrm{b}}$ \\
Phytate (mg/100 g) & $11.45 \pm 0.04^{\mathrm{c}}$ & $12.72 \pm 0.08^{\mathrm{a}}$ & $9.76 \pm 0.00^{\mathrm{e}}$ & $7.65 \pm 0.00^{\mathrm{f}}$ & $12.30 \pm 0.11^{\mathrm{b}}$ & $9.98 \pm 0.08^{\mathrm{d}}$ \\
Phenol (mg/100 g) & $1.75 \pm 0.00^{\mathrm{a}}$ & $1.04 \pm 0.02^{\mathrm{b}}$ & $0.34 \pm 0.02^{\mathrm{d}}$ & $0.18 \pm 0.00^{\mathrm{e}}$ & $0.97 \pm 0.04^{\mathrm{c}}$ & $0.94 \pm 0.03^{\mathrm{c}}$ \\
Tannin (mg/100 g) & $1.28 \pm 0.00^{\mathrm{f}}$ & $1.82 \pm 0.03^{\mathrm{d}}$ & $2.19 \pm 0.00^{\mathrm{a}}$ & $1.94 \pm 0.05^{\mathrm{c}}$ & $2.10 \pm 0.03^{\mathrm{b}}$ & $1.43 \pm 0.03^{\mathrm{e}}$ \\
Flavonoid (mg/100 g) & $4.00 \pm 0.00^{\mathrm{a}}$ & $2.00 \pm 0.00^{\mathrm{e}}$ & $3.00 \pm 0.00^{\mathrm{b}}$ & $2.75 \pm 0.07^{\mathrm{c}}$ & $2.70 \pm 0.00^{\mathrm{c}}$ & $2.40 \pm 0.14^{\mathrm{d}}$ \\
Phytosterol (mg/100 g) & $0.63 \pm 0.05^{\mathrm{c}}$ & $1.90 \pm 0.04^{\mathrm{a}}$ & $1.12 \pm 0.05^{\mathrm{b}}$ & $0.53 \pm 0.00^{\mathrm{d}}$ & $0.37 \pm 0.00^{\mathrm{e}}$ & $0.34 \pm 0.00^{\mathrm{e}}$ \\
\hline
\end{tabular}

Values are presented as means \pm standard deviation. Values with different superscripts in the same row are significantly different $(\mathrm{p}<0.05)$.

important essential micronutrients needed for normal body function. Zinc is reported to improve male fertility (Igile et al., 2013) and it is a component of multiple enzymes and proteins and is involved in the regulation of gene expression (FNB/IM/NA, 2001). Iron is a component of haemoglobin and numerous enzymes and is also required to prevent microcytic hypochromic anaemia (FNB/IM/NA, 2001).

\subsection{Phytochemicals}

The concentration of different phytochemicals found in the pepper foliage are shown in Table 4. Results indicated a significant difference $(p<0.05)$ in the phytochemical composition of the foliage. Hydrogen cyanide was in the range of $6.95-9.45 \mathrm{mg} / \mathrm{kg}$ with foliage from Scotch Bonnet pepper having the least value while Bird's eye pepper had the highest value. Hydrogen cyanide is a systemic poison whose toxic effects is due to the inhibition of cytochrome oxidase hence preventing the uptake of oxygen (NRC, 2002). Hydrogen cyanide is a hydrolysis product of cyanogenic glycosides. Cyanogenic glycosides are reduced by heat temperatures (Kemdirim et al., 1995). Therefore, there is need to process pepper leaves before consumption as opposed to direct use as salad ingredient.

Oxalate content of the pepper foliage ranged between 0.14 and $0.28 \mathrm{mg} / 100 \mathrm{~g}$. Abdel-Moemin (2014) classified foods with less than $10 \mathrm{mg}$ oxalate as low oxalate foods. Therefore, oxalate content of the pepper foliage identifies them as low oxalate vegetable/foliage. Alkaloids and saponins were in the range of $3-4.85 \%$ and $1-3 \%$ respectively. Foliage from Cayenne pepper had the highest alkaloid content while foliage from Anahiem pepper had the highest saponin content. Alkaloids are mostly nitrogenous heterocyclic compounds and have various biological activities when consumed by animals including man. Alkaloids have medicinal properties such as cytotoxicity, anti-spasmodic, analgesic and bactericidal properties (Stray, 1998). Oral ingestion of saponins at moderate concentrations through diet has beneficial effects such as being hypocholesterolemic, anti-cancer, anti-infertility and anti-inflammatory effects (Sodipo et al., 2000; Agiang et al., 2016).

Phytate content of the foliage ranged between 7.65 to $12.72 \mathrm{mg} / 100 \mathrm{~g}$. Cayenne pepper foliage had the highest concentration. Dietary phytates chelate divalent mineral cations, reducing their bioavailability and hence absorption; they also bind proteins and also reduce starch digestion (Uusiku et al., 2010). Akwaowo et al. (2000) stated that a phytic acid intake of 4-9 $\mathrm{mg} / 100 \mathrm{~g}$ reduces iron absorption in humans by $4-5$ fold. This implies that improper processing of the pepper foliage can reduce the bioavailability of divalent cationic minerals when consumed. However, phytate losses during cooking has been reported and can be due to interaction of hot water with plant cell walls which rupture and soluble phytates probably leach into the medium (Yadav and Sehgal, 2003). There is a need for heat processing of pepper foliage to ensure reduced phytate content before consumption. Its phytosterol content ranged between 0.34 to $1.90 \mathrm{mg} / 100 \mathrm{~g}$ with foliage from Cayenne pepper having the highest value.

Results indicated the presence of phenols, tannins and flavonoids in the pepper foliage. There were significant variations $(p<0.05)$ in these phytocompounds. The range of concentration of phenols, tannins and flavonoids were as follows: Phenols: $0.18-1.75 \mathrm{mg} / 100$ g; tannins: $1.28-2.19 \mathrm{mg} / 100 \mathrm{~g}$; flavonoids: $2-4 \mathrm{mg} / 100$ g. Anahiem pepper foliage had the highest phenolic and flavonoid contents while Bird's eye foliage had the highest tannin content. Flavonoid and tannin contents of the pepper foliages were higher than flavonoid (0.02$0.05 \mathrm{mg} / 100 \mathrm{~g})$ and tannin contents $(0.21-0.67 \mathrm{mg} / 100 \mathrm{~g})$ reported for lesser-known vegetables (Agiang et al., 2016). Phenols, tannins and flavonoids contribute to dietary intake of antioxidants because of free hydroxyl 
groups in their structures and they have varying biological effects. Antioxidative effect of phenolic compounds is due to their ability to serve as free radical terminators, hence having medicinal activity and exhibiting physiological functions (Ajayi et al., 2011). Flavonoids antioxidative outcome is owing to its free radical scavenging effect (Omale and Okafor, 2007). Tannins are a class of water-soluble phenolic compounds, and their biological effects depends on type/ class as well as concentration ingested. Tannin content of plant extracts influence their biological activity (Marsh et al., 2020). Wong et al. (2006) reported that plants which contain substantial quantities of polyphenols can exhibit strong antioxidant activity and contribute to their medicinal properties. This entails that what was present as phenolic, flavonoid and tannin contents in the respective pepper foliage can contribute to the beneficial effects attributed to them.

\section{Conclusion}

The findings from this study indicated variations in nutrient and phytochemical content of the respective pepper foliage. The high moisture content resulted to low nutrient density. Results indicated the presence of fatand water-soluble vitamins. Vitamins A, B1 and B2 contents of pepper leaves will be sufficient to meet with the recommended dietary allowance (RDA) for healthy individuals while older children and adults will have to supplement for vitamins E and D from other food sources. Oxalate was low but hydrogen cyanide and phytates were quite appreciable. Therefore, there is need for heat processing before consumption. The pepper foliage had beneficial phytochemicals such as phenols, tannins, flavonoids, saponins, alkaloids. The investigation of nutrients and phytochemicals present in this pepper foliage has provided information for the establishment of dietary guidelines on the consumption of pepper foliage. Therefore, consumption of any of the pepper foliage as vegetable may have additional value such as nutrition security and can prevent hidden hunger with respect to the high vitamin A content.

\section{References}

Abdel-Moemin, A.R. (2014). Oxalate content of Egyptian grown fruits and vegetablesand daily common herbs. Journal of Food Research, 3(3), 6677. https://doi.org/10.5539/jfr.v3n3p66

Abilgos-Ramos, R., Mamucod, H. and Corpuz, G. (2012). Chili pepper leaves an alternative source of micronutrients. Philippine Journal of Crop Science, 37(1), 139.

Agiang, M., Mbang, J., Essien, N. and Peters, H. (2016). Proximate and phytochemical composition of some lesser known vegetables consumed in Northern Senatorial District of Cross River State of Nigeria. World Journal of Nutrition and Health, 4(1), 16-21.

Ajayi, G.O., Olagunji, J.A., Ademuyiwa, O. and Martins, O.C. (2011). Gas chromatography-Mass spectrometry analysis and phytochemical screening of ethanolic extract of Plubangozeylanica, Linn. Journal of Medicinal Plants Research, 5(9), 17561761.

Akwaowo, E.U., Ndon, B.A. and Etuk, E.U. (2000). Minerals and antinutrients in fluted pumpkin (Telferia occidentalis Hook. F). Food Chemistry, 70 (2), 235-240. https://doi.org/10.1016/S0308-8146 (99)00207-1

Alfawaz, M.A. (2006). Chemical composition of hummayd (Rumex vesicarius) grown in Saudi Arabia. Journal of Food Composition Analysis, 19(6 -7), 552-555. https://doi.org/10.1016/ j.jfca.2004.09.004

Asibey-Berko, E. and Tayie, F.A.K. (1999). Proximate analysis of some underutilized Ghanaian vegetables. Ghana Journal of Science, 39, 91-96. https:// doi.org/10.4314/gjs.v39i1.15862

Bosland, P.W. (1996). Capsicums: Innovated uses of an ancient crop. In Janick, J. (Ed). Progress in new crops. Arlington, USA: ASHS Press.

Brown, C., Clement, C., Epps, P., Luedeling, E. and Wichmann, S. (2013). The Paleobialinguistics of domesticated chili pepper (Capsicum spp). Ethnobiology Letters Society of Ethnobiology, 4, 111. https://doi.org/10.14237/ebl.4.2013.2

Ejoh, A.S., Tchouanguep, M.F. and Fokou, E. (1996). Nutrient composition of the leaves and flowers of Colocasia esculenta and the fruits of Solanum melongena. Plant Foods for Human Nutrition, 49(2), 107-112.https://doi.org/10.1007/BF01091966

Food and Agricultural Organisation, FAO. (2003). Food Energy-Methods of analysis and conversion factorsFAO Food and Nutrition paper 77. Report of a Technical Workshop. Rome Food and Agriculture Organization of the United Nations.

Food and Nutrition Board, Institute of Medicine National Academies (FNB/IM/NA). (2001). Dietary reference intakes for vitamin $\mathrm{A}$, vitamin $\mathrm{K}$, Arsenic, Boron, Chromium, Copper, Iodine, Iron, Manganese, Molybdenum, Nickel, Silicon, Vanadium and Zinc. Washington, D.C., USA: The National Academies of Sciences Engineering Medicine.

Food and Nutrition Board, Institute of Medicine, National Academies (FNB/IM/NA). (1997). Dietary reference intakes for calcium, phosphorus, magnesium, vitamin $\mathrm{D}$ and flouride. Washington, 
D.C., USA: The National Academies of Sciences Engineering Medicine.

Food and Nutrition Board, Institute of Medicine, National Academies (FNB/IM/NA). (1998). Dietary reference intakes for thiamin, riboflavin, niacin, vitamin $\mathrm{B}_{6}$, folate, Vitamin $\mathrm{B}_{12}$, panthothenic acid, biotin and choline. Washington, D.C., USA: The National Academies of Sciences Engineering Medicine.

Food and Nutrition Board, Institute of Medicine, National Academies (FNB/IM/NA). (2000). Dietary reference intakes for vitamin $\mathrm{C}$, vitamin $\mathrm{E}$, selenium and carotenoids. Washington, D.C., USA: The National Academies of Sciences Engineering Medicine.

Food and Nutrition Board, Institute of Medicine, National Academies (FNB/IM/NA). (2004). Dietary reference intakes for water, potassium, sodium, chloride and sulfate. Washington, D.C., USA: The National Academies of Sciences Engineering Medicine.

Giskes, K., Turrell, G., Patterson, C. and Newman, B. (2002). Socio-economic differences in fruits and vegetable consumption among Australian adolescents and adults. Public Health Nutrition, 5(5), 663-669. https://doi.org/10.1079/PHN2002339

Greenfield, H. and Southgate, D.A.T. (2003). Review of methods of Analysis. In Burlingame, B.A and Charrondiere, U.R (Eds.). Food composition data, production, management and use. Rome: Food and Agricultural Organization of the United Nations.

Gupta, S., Jyothi Lakshmi, A., Manjunath, M.N. and Prakash, J. (2005). Analysis of nutrient and antinutrient content of underutilized green leafy vegetables. LWT - Food Science and Technology, 38 (4), 339-345. https://doi.org/10.1016/ j.lwt.2004.06.012

Harborne, J.B. (1998). Phytochemical methods: A guide to modern techniques of plant analysis. $3^{\text {rd }} \mathrm{ed}$. London: Chapman and Hall.

Igile, G.O., Iwara, I.A., Mgbeje, B.I.A., Uboh, F.E. and Ebong, P.E. (2013). Phytochemical, proximate and nutrient composition of Vernonia amygdalina Hook (Astreacea): A green- leafy vegetable in Nigeria. Journal of Food Research, 2(6), 1-11. https:// doi.org/10.5539/jfr.v2n6p1

Jackson, M.L. (1969). Soil chemical analysis advanced course. In IITA. Selected methods for soil and plant analysis. Ibadan Manual series No.1. MadisonWisconsin, USA: Department of Soil Science, University of Wisconsin.

James, C.S. (Ed.) (1995). Analytical Chemistry of Foods.
Boston, USA: Springer. https://doi.org/10.1007/978$1-4615-2165-5$

Kasal, A., Budesinsky, M. and Griffiths, W.J. (2010). Spectroscopic Methods of Steroid Analysis. In Makin, H.L.J. and Gower, D.B. (Eds.), Steroid Analysis, p. 27-161. Dordrecht, Netherlands: Springer. https://doi.org/10.1023/b135931_2

Kemdirim, O.C., Chukwu, O.A. and Achinewhu, S.C. (1995). Effects of traditional processing of cassava on the cyanide content of garri and cassava flour. Plant Foods for Human Nutrition, 48, 335339.https://doi.org/10.1007/BF01088492

Marsh, K.J., Wallis, I.R. Kulheim, C., Clark, R., Nicolle, D., Foley, W.J and Salminen, J.P. (2020). New approaches to tannin analysis of leaves can be used to explain in vitro biological activities associated with herbivore defence. New Phytology, 225(1), 488498. https://doi.org/10.1111/nph.16117

Medoua, G.N. and Oldewage-Theron, W.H. (2014). Effect of drying and cooking on nutritional value and antioxidant capacity of Morogo (Amaranthus hybridus) a traditional leafy vegetable grown in South-Africa. Journal of Food Science and Technology, 51(4), 736-742. https://doi.org/10.1007/ s13197-011-0560-4

Nadeeshani, H., Wimalasiri, K.M.S., Samarasinghe, G., Silva, R. and Madhujith, T. (2018). Evaluation of the nutritional value of selected leafy vegetables grown in Sri Lanka. Tropical Agricultural Research, 29(3), 255-267.https://doi.org/10.4038/tar.v29i3.8265

Natesh, H.N., Abbey, L. and Asiedu, S.K. (2017). An overview of nutritional and antinutritional factors in green leafy vegetables. Horticulture International Journal, 1(2), 58-65. https://doi.org/10.15406/ hij.2017.01.00011

National Research Council (NRC). (2002). Hydrogen cyanide: Acute exposure guideline levels. Subcommittee on acute exposure guideline levels. Washington, D.C., USA: National Academies Press.

Official Methods of Analysis of the Association of Official Analytical Chemists (AOAC). (2005). 15 ${ }^{\text {th }}$ ed. USA: AOAC.

Okpalamma, F., Ojimelukwe, P.C. and Akachukwu, D. (2016). Post-harvest storage and processing changes in carotenoids, chlorophylls and micronutrients in Pterocarpus mildbraedii. American Association for Science and Technology-Journal of Biology, 29(1), 1 $-9$.

Okpalamma, F., Ojimelukwe, P.C. and Mazi, E.A. (2013). Post-harvest storage and processing changes in carotenoids and micronutrients in fluted pumpkin (Telferia occidentalis Hook.F). IOSR-Journal of 
Agriculture and Veterinary Science, 6(4), 34-39. https://doi.org/10.9790/2380-0643439

Okwu, D.E. and Emenike, I.N. (2006). Evaluation of the phytonutrients and vitamins content of citrus fruits. International Journal of Molecular Medicine and Advance Sciences, 2(1), 1 - 6.

Omale, J. and Okafor, P.N. (2007). Comparative antioxidant capacity, membrane stabilization, polyphenol composition and cytotoxicity of the leaf and stem of Cissus multistriata. African Journal of Biotechnology, 7(17), 3129-3133.

Otitoju, G.T.O., Ene-Obong, H.N and Otitoju, O. (2014). Macro and micro nutrient composition of some indeginous green leafy vegetables in South-east zone, Nigeria. Journal of Food Processing and Technology, 5, $1000389 . \quad \mathrm{https} / /$ doi.org/10.4172/2157-7110.1000389

Rhodes, D. (2009). HORT-410-Vegetable Crops-Pepper Notes. Department of Horticulture and Landscape Architecture, Purdue University West Lafayette, IN47907-2010. Retrieved September 22, 2020 from website: www.hort.purdue.edu

Säbel, C.E., Neureuther, J.M. and Siemann, S. (2010). A spectrophotometric method for the determination of zinc, copper, and cobalt ions in metalloproteins using Zincon. Analytical Biochemistry, 397(2), 218226.https://doi.org/10.1016/j.ab.2009.10.037

Sodipo, O.A., Akiniyi, J.A. and Ogunbamosu, J.U. (2000). Studies on certain characteristics of extracts of bark of RansinystaliaMacruceras (K. Schemp) piccreExbeille. Global Journal of Pure and Applied Science, 6(1), 83-87. https://doi.org/10.4314/ gjpas.v6i1.16082

Specialty Produce. (2020). Thai pepper leaves. Retrieved August 8, 2020 from Specialty Produce website: https://specialtyproduce.com/produce/

Thai_Pepper_Leaves_9645.php

Stephens, M.J. (2002). Secondary edible parts of vegetables, vegetable production and marketing news. In Dainello, F.J. (Ed.) Vegetable Production and Marketing News. Texas, USA: Extension Horticulture, Texas Cooperative Extension, The Texas A\&M University System.

Stray, F. (1998). The natural guide to medicinal herbs and plants. London: Tiger Books International.

Ulgeret, T.G., Songur, A.N., Çirak, O and Çakiroğlu, F.P. (2018). Roles of vegetables in human nutrition and disease prevention. In Asaduzzaman, Md. and Asao, T. (Eds.). Vegetables - Importanceof quality vegetables to human health. InTech Open E-Book.

Uusiku, N.P., Oelofse, F., Duodu, K.G., Bester, M.J. and Faber, M. (2010). Nutritional value of leafy vegetables of sub-Saharan Africa and their potential contribution to human health: a review. Journal of Food Composition and Analysis, 23(6), 499-509. https://doi.org/10.1016/j.jfca.2010.05.002

Wong, S.P., Leong, L.P. and Kola, J.H.W. (2006). Antioxidant activities of aqueous extracts of selected plants. Food Chemistry, 99(4), 775-783.https:// doi.org/10.1016/j.foodchem.2005.07.058

Yadav, S.K and Sehgal, S. (2003). Effect of domestic processing and cooking on selected antinutrient contents of some given leafy vegetables. Plant Foods for Human Nutrition, 58(3), 1-11. https:// doi.org/10.1023/B:QUAL.0000040359.40043.4f

Yasmin, A., Zeb, A., Khalil, A.W., Paracha, G.M. and Khattak, A.B. (2008). Effect of processing on antinutritional factors of Red Kidney Bean (Phaseolus vulgaris) grains. Food and Bioprocess Technology, 1, 415-419. https://doi.org/10.1007/s11947-008-0125 $-3$ 